\title{
FOOD PREFERENCES OF THE GREAT RAMSHORN PLANORBARIUS CORNEUS (LINNAEUS, 1758) ALLOSPECIES (MOLLUSCA: GASTROPODA: PLANORBIDAE) FROM THE UKRAINIAN RIVER SYSTEM
}

\author{
YULIIA BABYCH $^{1}$, OLENA UVAYEVA ${ }^{2 *}$, AGNESSA STADNYCHENKO ${ }^{1}$
}

\author{
${ }^{1}$ Zhytomyr Ivan Franko State University, Velyka Berdychivska Str. 40, 10008 Zhytomyr, Ukraine \\ (e-mails: b_yulia@i.ua, stadnychenko2016@gmail.com); (1) YB https://orcid.org/0000-0001-6887-0529, \\ (1) AS https://orcid.org/0000-0001-7738-4776 \\ ${ }^{2}$ Zhytomyr Polytechnic State University, Chudnivska Str. 103, 10005 Zhytomyr, Ukraine \\ (e-mail: bio-2016@ukr.net); (1) https://orcid.org/0000-0003-1894-0386 \\ *corresponding author
}

\begin{abstract}
The "western" and "eastern" allospecies of the superspecies complex Planorbarius corneus (Linnaeus, 1758) sensu lato includes the most widespread and abundant gastropods in the Ukrainian aquatic fauna. The range of the "western" allospecies includes the north and central parts of Right Bank Ukraine, while the range of the "eastern" allospecies comprises the north-eastern and eastern parts of Left Bank Ukraine, and the extreme south (as far as the Danube River) of the Ukrainian steppe zone. The food preferences of these snails were established for the first time. Such data may provide the basis for studying the role of both allospecies in the food webs of the river systems of Ukraine.
\end{abstract}

KEY WORDS: allospecies; Planorbarius corneus sensu lato; food preferences

\section{INTRODUCTION}

The genetic marking, applied in the early 21 st century to study the genetic frequencies for Planorbarius corneus (Linnaeus, 1758) in Ukraine, demonstrated its apparent superspecies status ( $P$. corneus sensu lato) with two genetically distinct vicariant allospecies - "western" and "eastern" (GARBAR 2003, GARBAR \& GARBAR 2005, 2006, MEZHZHERIN et al. 2005). Their morphological (conchological and anatomical), ecological and chorological features differ statistically significantly.

The conchological differences between the "western" and "eastern" allospecies are the absolute shell size (larger in the former form) and six metric indices describing the rate of whorl increment and the height/width ratio of the aperture. However, application of such parameters for allospecies delimitation is somewhat complicated due to the geographical variation of their conchological features along the north-south and west-east gradients. Their absolute shell size and their metric indices increase from north to south, and decrease from west to east. At the same time, conchiolin layer colouration of each allospecies remains constant: usually dark-brown to black in the "western" form and much lighter (hazel, brown-yellow or yellow-grey) in the "eastern" form.

The differences in some characters of the reproductive system (vagina, spermatheca and its ducts) and the related indices are also statistically significant. It should be emphasised that the genetically described allospecies are much more reliably distinguishable based on their anatomical features, than on conchological features only (GARBAR \& GARBAR 2006).

The ranges of the two allospecies are geographically separated. The "western" form occupies the 
river system in the western and central regions of Right Bank Ukraine, while the "eastern" form inhabits the north-eastern and eastern regions of Left Bank Ukraine and the extreme south of the Ukrainian steppe zone on both banks (including the Danube River). There is a relatively narrow (approximately $100 \mathrm{~km}$ ) zone of introgressive hybridisation between these ranges. The spatial separateness of the two allospecies is the result of their different ecological requirements. It depends primarily on their adaptation to the degree of drought in their respective ranges. The "western" allospecies inhabits Right Bank, where the annual drought rate does not exceed $1 \%$ of days, whereas the "eastern" allospecies lives in more severe conditions of Left Bank: the drought probability here reaches $1-10 \%$ of days per year, and in the extreme south of the steppe zone it exceeds $10 \%$. This is undoubtedly reflected in the productivity of aquatic vegetation which is the basic food source of these molluscs.

The exogenous and endogenous stages of mollusc feeding and digestion are reflected in their complex feeding behaviour, manifest as a sequence of processes: foraging, digestion, absorption and assimilation. Foraging is determined by preferences to particular, selected food. Food preferences of the great ramshorn allospecies have not been established to date.

\section{MATERIAL AND METHODS}

Samples were taken by YU. BABYCH in July 2019. Two localities were sampled: Teteriv River and Vorskla River (Figs 1-3). In each of them a $200 \mathrm{~m}$ section of the river channel was divided into six sampling sites distributed at $40 \mathrm{~m}$ intervals. The total number of samples per locality was 237 and 198, respectively.
The main method used was hand-collecting from the surface of water plants, river bottom and artificial materials (e.g. plastic bottles and bags) combined with washing the sediment on a metal sieve (diameter $20 \mathrm{~cm}, 2 \mathrm{~cm}$ mesh).

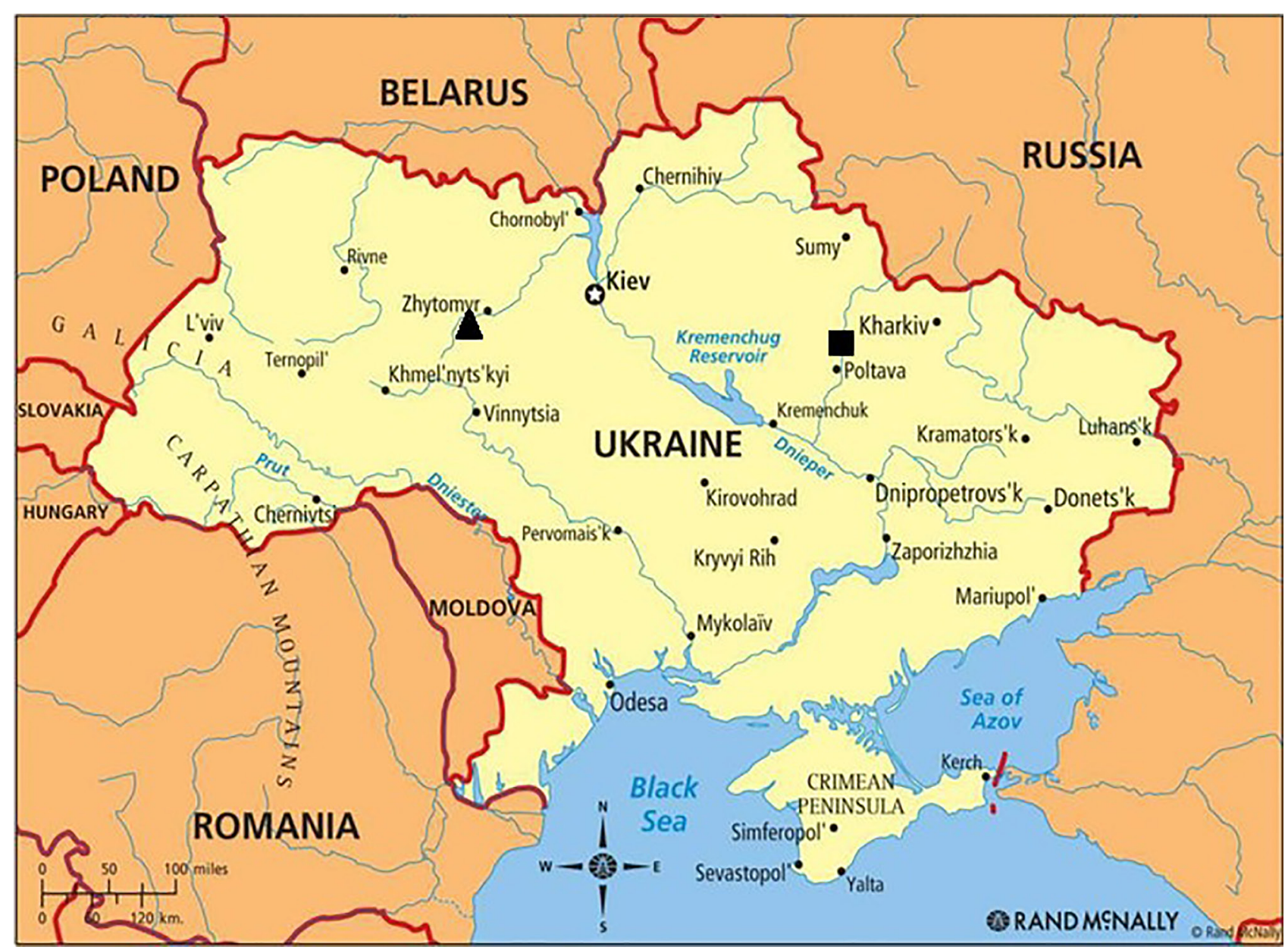

Fig. 1. Map showing the type localities of Planorbarius corneus sensu lato: black triangle - "western"; black square - "eastern" allospecies 

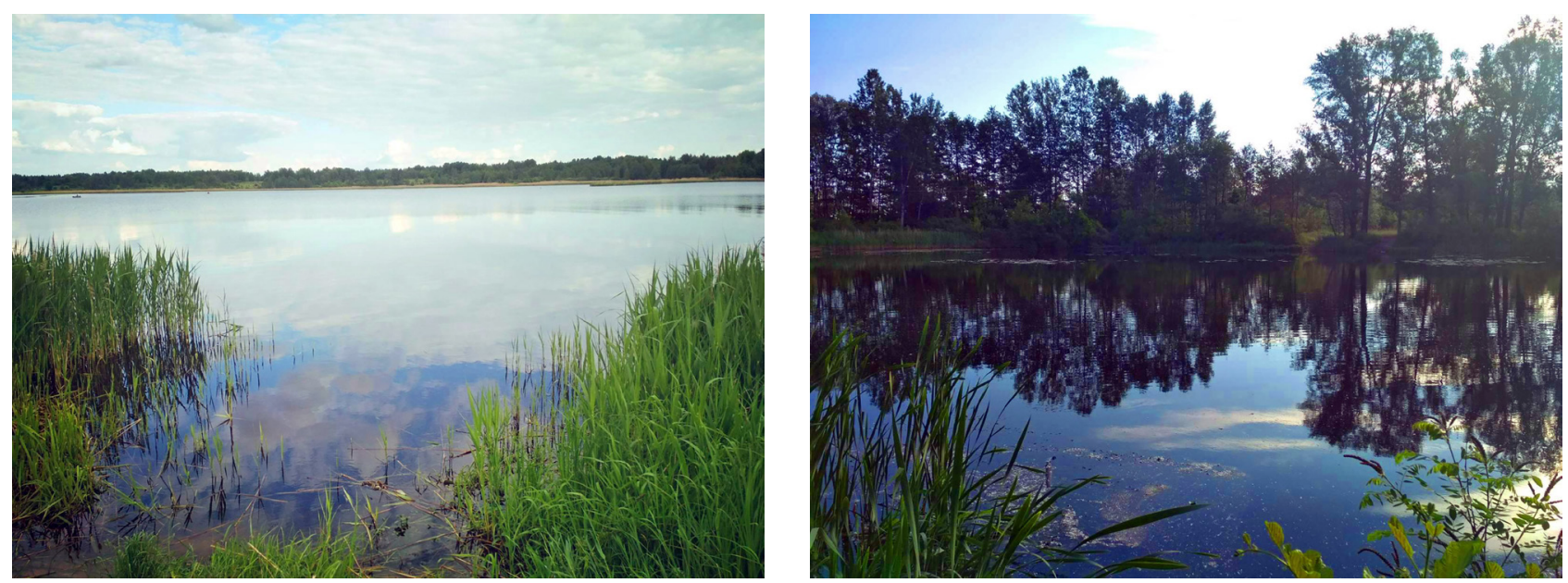

Figs 2-3. Habitats of Planorbarius corneus in 2019: 2 - River Teteriv (village Korchak, Zhytomyr region); 3 - River Vorskla (village Semyanivka, Poltava region). Photos: YULIIA BABYCH

Taxonomic identification was performed according to the following scheme. First, six individuals from each sample were subject to electrophoresis in $7.5 \%$ polyacrylamide gel in Tris-borate-EDTA buffer (ph = 8.5) during 1 h $20 \mathrm{~min}(200 \mathrm{~V}, 140 \mathrm{~mA})$ (PEACOCK et al. 1965). The rest of the collected material was identified conchologically. Metric indices were calculated: absolute shell size, indices of the rate of whorl increment and height/width ratio of the aperture. We also considered the colouration and transparency of the conchiolin layer. In doubtful cases we resorted to anatomical features: size of spermatheca reservoir and its ducts and the related indices (MEZHZHERIN et al. 2005). In total, we identified 207 individuals as the "western" and 168 individuals as the "eastern" allospecies.

Sixty one and 63 individuals, respectively, were used in the experiments aimed at studying the qualitative (DANILOVA 1991) and quantitative (DUKA \& SINYUKOVA 1976) food preferences under natural conditions. To investigate the degree of preference for various food components, the stomachs of experimental individuals were dissected; the food masses were placed on slides and immersed in a mixture of methanol, glycerin and distilled water. The slides were stained with 5\% erythrosine and examined under the microscope (Biolam LOMO, $\times 56)$. The frequency of fragments of each food category was calculated as the proportion of observations of each food category in the total number of examined food masses.

The odontophore with pharynx parts was extracted from each dissected mollusc to prepare the microscopic slide following SITNIKOVA \& STAROBOGATOV's (1985) method. The odontophore was boiled in $10 \%$ $\mathrm{NaOH}$ for 1-2.5 min (till complete destruction of soft tissues and radula release). The radula, cleaned and rinsed in distillate, was then placed on the slide and straightened. Then the slides were covered with cover slips with an air layer underneath, and sealed with Canada balsam.

The main trophological indices were ascertained for 146 and 105 individuals of the "western" and "eastern" allospecies, respectively. The experiments were preceded by 14-hour acclimation of selected individuals to aquarium conditions following KHLeBOVICH (1985): $20 \mathrm{~L}$ tanks, density 5 ind./L, temperature $19-21{ }^{\circ} \mathrm{C}, \mathrm{pH}$ 8.1-8.4, oxygenation $7.9-8.4 \mathrm{mg} / \mathrm{dm}^{3} \mathrm{O}_{2}$. The animals were fed with soft vascular plants taken from the snails' natural habitat.

The mean volume of daily ration (VMR, \%) was estimated using SUSHKINA's method (1949). Selected animals were dried on filter paper and weighed with electronic scales WPS 1200/C; their shells were measured with callipers ( $0.1 \mathrm{~mm}$ accuracy). Then each of them was placed singly in a $0.5 \mathrm{~L}$ glass tank with water settled for a day, and with a food portion. The food portions were pre-dried on filter paper under the pressure of $1 \mathrm{~kg}$ for $20 \mathrm{~min}$. The aquarium environment was renewed every day. After twoday exposure, unconsumed food was removed and weighed in the same way. The difference between the pre- and post-exposure food mass indicated its daily consumption (expressed as percentage of total mollusc mass).

The time of food passage through the digestive system (DPF, min) was estimated using VYSKUSHYENKO's method (2002). Selected animals were fed with macerated (4-6 days) carrot pieces (2-3 mm) for a week till they started to produce orange faeces. Then they were placed singly in the 0.5 $\mathrm{L}$ tanks with water and a green food portion. The DPF was calculated as the time between the start of feeding on the green food and the first appearance of dark-coloured faeces.

The coefficient of food assimilation (CAF, \%) was obtained with the direct method following TSIKHONLUKANINA (1987). The experimental animals were 
placed singly in $0.5 \mathrm{~L}$ tanks with water and dried and weighed food portions. The mass difference between the initial and unconsumed food was adopted as the individual daily consumption rate. Then the water from the tanks was filtered, and the obtained faeces were dried on filter paper for 20 min under 1 kg pressure and weighed (scales WPS 1200/C). The coefficient was calculated as the ratio of the difference between the daily food consumption and the faeces' mass to the daily mass of produced faeces.

The rates of daily excrement production (RDPE) and assimilation (RDA) were estimated according to
PETRUSEWICZ \& MACFADYEN (1970). The RDPE was calculated as the ratio of the daily excrement production to the snail mass, and the RDA was calculated as the ratio of the difference between the daily food consumption and the daily mass of faeces to the snail mass.

Separation the food plants into the soft and tough followed SADCHIKOV \& KUDRYASHOV (2004). Soft plants are usually rooted or floating, with reduced mechanical tissue. Tough macrophytes are always rooted and semi-immersed, with well-developed mechanical tissue.

\section{RESULTS}

The "western" allospecies (Figs 4-6) was collected in the Teteriv River (right tributary of the Dnipro River) close to Korchak $\left(50^{\circ} 12.57^{\prime} \mathrm{N}, 28^{\circ} 28.78^{\prime} \mathrm{E}\right.$, 11.07.2019, Figs 1-2). The mean shell size in $\mathrm{mm}$ was: $26.47 \pm 0.16$ diameter, $13.02 \pm 0.06$ aperture height. The radular formula was:

$$
\left[\frac{c}{2}+\left(\frac{1-9}{3}+\frac{10-15}{5}+\frac{16-38}{6}\right) \times 2\right] \times 150
$$
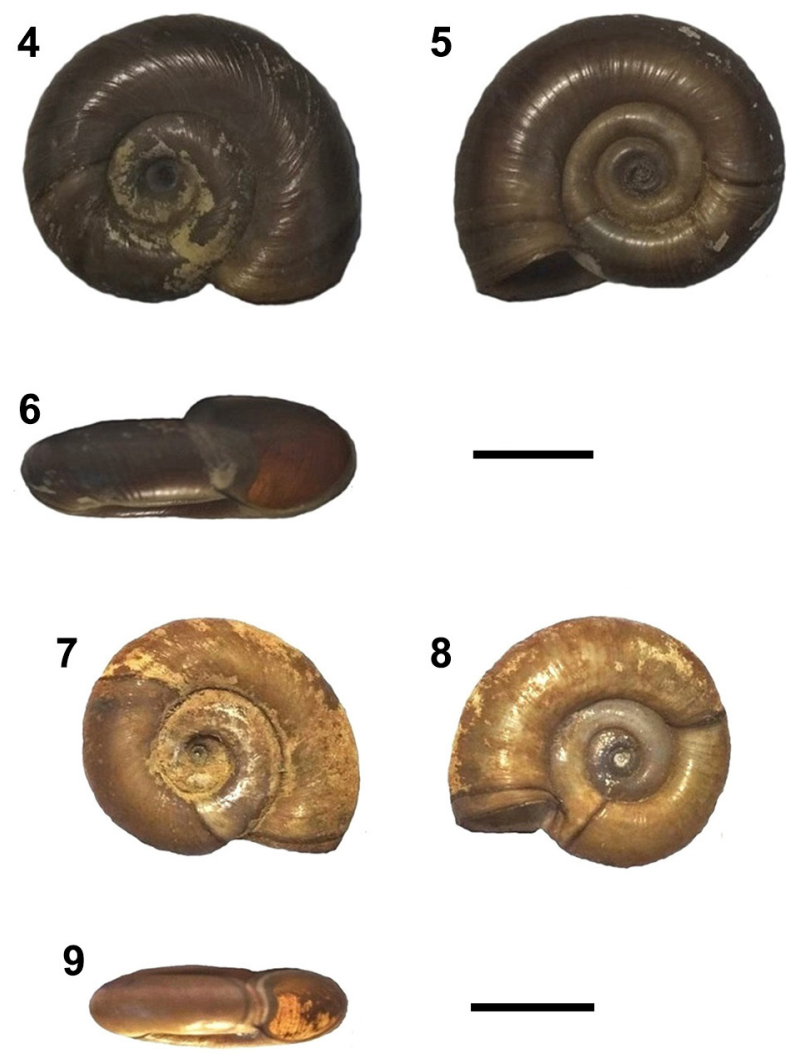

Figs 4-9. Shells of Planorbarius corneus sensu lato: 4-6 "western"; 7-9 - "eastern" allospecies. Scale bars: 10 mm. Photos: YuliIA BABYCH

In the shallow zone the form was found in dense beds of Cladophora sp. at the depth of 4-5.5 cm with the density of 5-9 ind. $/ \mathrm{m}^{2}$. In the riparian zone with its rich soft vegetation, it was found on the same plants at the depth of 0.7-1.2 m. In the benthic zone the snails aggregated with the density of 9-11 ind./ $\mathrm{m}^{2}$ in places without macrophytes, covered by plant detritus.

The "eastern" allospecies (Figs 7-9) was collected in the Vorskla River (left tributary to the Dnipro River) close to Semianivka $\left(49^{\circ} 40.48^{\prime} \mathrm{N}, 34^{\circ} 36.18^{\prime} \mathrm{E}\right.$, 29.07.2019, Figs 1, 3). It should be emphasised that the two localities, where the material was sampled, were quite similar in terms of their spatial (latitudinal) situation. The mean shell size of this allospecies in $\mathrm{mm}$ was: $24.98 \pm 0.23$ diameter, $12.33 \pm 0.06$ aperture height. The radular formula was:

$$
\left[\frac{c}{2}+\left(\frac{1-9}{3}+\frac{10-14}{5}+\frac{15-38}{5}\right) \times 2\right] \times 150 .
$$

The morphological types of ramshorn's radular teeth: initial (central), lateral, intermediate and extreme are presented in Fig. 10.

In the shallow zone this form was found at the depth of 3.5-6 cm, with the density of 6-12 ind. $/ \mathrm{m}^{2}$.

II
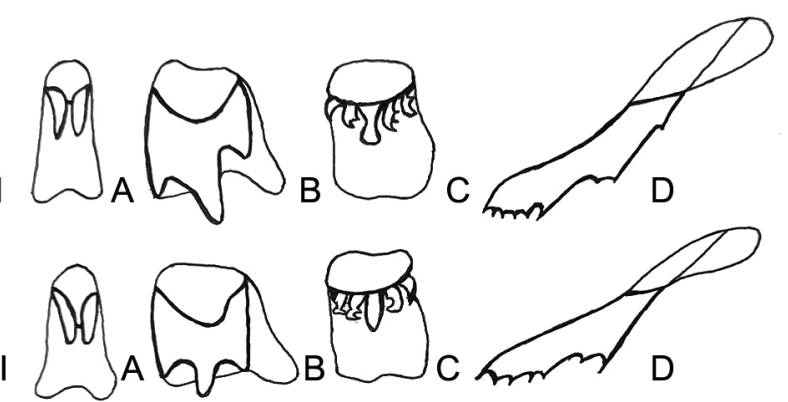

Fig. 10. Teeth of ramshorn's radula (I - allospecies "western", II - allospecies "eastern"): A - initial (central) tooth; B - first lateral tooth; C - intermediate tooth; D - extreme tooth 
Table 1. Qualitative composition and quantitative ratio (\%) of great ramshorn allospecies ration components

\begin{tabular}{|c|c|c|c|c|c|c|c|c|c|}
\hline \multirow[b]{2}{*}{$\begin{array}{l}\text { n, } \\
\text { ind. }\end{array}$} & \multirow[b]{2}{*}{$\begin{array}{l}\text { Bacteria } \\
M \pm m_{x}\end{array}$} & \multicolumn{3}{|c|}{ Algae } & \multicolumn{2}{|c|}{ Flowering plants } & \multirow[b]{2}{*}{$\begin{array}{l}\text { Detritus } \\
\mathrm{M} \pm \mathrm{m}_{\mathrm{x}}\end{array}$} & \multirow[b]{2}{*}{$\begin{array}{l}\text { Allochtho- } \\
\text { nous } \\
\text { material } \\
{\mathrm{M} \pm \mathrm{m}_{\mathrm{x}}}\end{array}$} & \multirow[b]{2}{*}{$\begin{array}{l}\text { Sand, mud } \\
\quad M \pm m_{x}\end{array}$} \\
\hline & & $\begin{array}{c}\text { Green } \\
\text { (unicellular) } \\
\mathrm{M} \pm \mathrm{m}_{\mathrm{x}}\end{array}$ & $\begin{array}{l}\text { Filamentous } \\
\qquad \mathrm{M} \pm \mathrm{m}_{\mathrm{x}}\end{array}$ & $\begin{array}{l}\text { Diatomes } \\
M \pm m_{x}\end{array}$ & 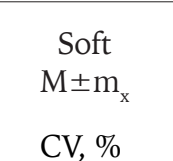 & $\begin{array}{l}\text { Harsh } \\
M \pm m_{x}\end{array}$ & & & \\
\hline \multicolumn{10}{|c|}{ "western" allospecies } \\
\hline 61 & $6.52 \pm 0.79$ & $3.00 \pm 0.14$ & $29.07 \pm 1.05$ & $5.06 \pm 1.15$ & $28.63 \pm 2.01$ & $2.50 \pm 0.24$ & $14.01 \pm 2.09$ & $1.51 \pm 0.13$ & $10.00 \pm 1.11$ \\
\hline \multicolumn{10}{|c|}{ "eastern" allospecies } \\
\hline 63 & $\begin{array}{c}1.13 \pm 0.21 \\
97.80\end{array}$ & $\begin{array}{c}5.08 \pm 0.07 \\
94.60\end{array}$ & $\begin{array}{c}35.91 \pm 1.18 \\
95.00\end{array}$ & $\begin{array}{c}7.43 \pm 1.37 \\
94.60\end{array}$ & $\begin{array}{c}21.25 \pm 1.60 \\
95.60\end{array}$ & $1.00 \pm 0.18$ & $\begin{array}{c}10.40 \pm 1.10 \\
95.70\end{array}$ & $1.54 \pm 0.17$ & $9.51 \pm 1.25$ \\
\hline
\end{tabular}

In the vegetated zone at the depth of $0.5-1.25 \mathrm{~m}$ it aggregated with the density of $11-21$ ind. $/ \mathrm{m}^{2}$. Both allospecies were frequently found in the underwater sites with tough plants: on Scirpus sp. and Phragmites sp. in the Teteriv, and additionally on Carex sp. and Typha sp. in the Vorskla.

The snails were also found directly on the surface of bottom sediments (7-13 ind. $/ \mathrm{m}^{2}$ ) covered by detritus layer $(0.5-2$ and $2.5-4.9 \mathrm{~cm}$ in the Vorskla and in the Teteriv, respectively).

Table 2. Filling level (points) of cardial stomach part in great ramshorn allospecies

\begin{tabular}{|c|c|c|c|c|}
\hline \multirow{2}{*}{$\mathrm{n}$, ind. } & \multicolumn{4}{|c|}{ Index } \\
\hline & $\lim$ & $\mathrm{M} \pm \mathrm{m}_{\mathrm{x}}$ & $\delta$ & $\mathrm{CV}, \%$ \\
\hline \multicolumn{5}{|c|}{ "western" allospecies } \\
\hline 48 & $0-3$ & $2.89 \pm 0.17$ & 1.59 & 56.18 \\
\hline \multicolumn{5}{|c|}{ "eastern" allospecies } \\
\hline 39 & $0-3$ & $2.46 \pm 0.16$ & 1.43 & 51.32 \\
\hline
\end{tabular}

Both allospecies are obligate phytophages. Their foraging mode is grazing performed in three ways: with the radula and orchestrated work of the complex pharynx muscle apparatus, using odontophore and radula to scrape the tissue from food plants (1); biting off the pieces of food with three sharp jaws (central spinal and two bottom-lateral) (2); detritophagy using sharp lateral teeth of their radula to pick up the largest particles of detritus and convey them to the mouth by (3).

The digestive mass is formed in the cardial stomach part, from the swallowed food. Its qualitative and quantitative composition allowed us to approximately estimate the food preferences (to particular food species) of each allospecies under both natural (Tables 1, 2) and laboratory (Table 3) conditions.

Table 3. The main trophological indices of great ramshorn allospecies

\begin{tabular}{|c|c|c|c|c|c|c|}
\hline Food objects & $\mathrm{n}$ & $\begin{array}{l}\text { VMR, \% } \\
M \pm m_{x} \\
C V, \%\end{array}$ & $\begin{array}{c}\mathrm{DPF}, \min \\
\mathrm{M} \pm \mathrm{m}_{\mathrm{x}} \\
\mathrm{CV}, \%\end{array}$ & $\begin{array}{l}\text { CAF, \% } \\
M \pm m_{x} \\
C V, \%\end{array}$ & $\begin{array}{l}\text { RDPE } \\
M \pm m_{x} \\
C V, \%\end{array}$ & $\begin{array}{l}\mathrm{RDA} \\
\mathrm{M} \pm \mathrm{m}_{\mathrm{x}} \\
\mathrm{CV}, \%\end{array}$ \\
\hline \multicolumn{7}{|c|}{ "western" allospecies } \\
\hline Cladophora glomerata & 31 & $4.31 \pm 0.42$ & $440.30 \pm 31.15$ & $61.21 \pm 11.40$ & $0.0175 \pm 0.0010$ & $0.0308 \pm 0.0021$ \\
\hline Myriophyllum spicatum & 33 & $3.42 \pm 0.40$ & $421.02 \pm 20.03$ & $49.30 \pm 10.04$ & $0.0290 \pm 0.0009$ & $0.0292 \pm 0.0017$ \\
\hline Nymphaea candida & 21 & $4.27 \pm 0.29$ & $451.21 \pm 23.01$ & $56.01 \pm 9.08$ & $0.0112 \pm 0.0011$ & $0.0252 \pm 0.0014$ \\
\hline Potamogeton perfoliatus & 19 & $1.18 \pm 0.17$ & $489.39 \pm 28.86$ & $51.34 \pm 7.03$ & $0.0296 \pm 0.0009$ & $0.0121 \pm 0.0016$ \\
\hline Elodea canadensis & 22 & $0.24 \pm 0.02$ & $501.16 \pm 40.01$ & $43.54 \pm 7.03$ & $0.0191 \pm 0.0008$ & $0.0172 \pm 0.0002$ \\
\hline Lemna minor & 20 & $0.19 \pm 0.01$ & $501.28 \pm 31.17$ & $40.03 \pm 7.38$ & $0.0074 \pm 0.0005$ & $0.0050 \pm 0.0004$ \\
\hline \multicolumn{7}{|c|}{ “eastern" allospecies } \\
\hline Cladophora glomerata & 15 & $4.12 \pm 0.45$ & $\begin{array}{c}459.12 \pm 29.16 \\
96.50\end{array}$ & $63.10 \pm 9.13$ & $0.0189 \pm 0.0115$ & $0.0338 \pm 0.0021$ \\
\hline Myriophyllum spicatum & 23 & $3.16 \pm 0.35$ & $428.08 \pm 19.10$ & $51.05 \pm 10.02$ & $\begin{array}{c}0.0145 \pm 0.0009 \\
96.70\end{array}$ & $\begin{array}{c}0.0312 \pm 0.0017 \\
95.60\end{array}$ \\
\hline Nymphaea candida & 12 & $4.50 \pm 0.42$ & $454.41 \pm 15.14$ & $\begin{array}{c}57.03 \pm 5.13 \\
95.60\end{array}$ & $0.0174 \pm 0.0013$ & $0.0327 \pm 0.0022$ \\
\hline Potamogeton perfoliatus & 15 & $1.22 \pm 0.10$ & $\begin{array}{c}397.17 \pm 20.21 \\
98.90\end{array}$ & $\begin{array}{c}53.10 \pm 9.01 \\
95.70\end{array}$ & $0.0140 \pm 0.0011$ & $0.0202 \pm 0.0010$ \\
\hline Elodea canadensis & 19 & $\begin{array}{c}0.20 \pm 0.01 \\
95.00\end{array}$ & $507.51 \pm 19.02$ & $46.01 \pm 11.12$ & $\begin{array}{c}0.0143 \pm 0.0009 \\
95.40\end{array}$ & $0.0125 \pm 0.0003$ \\
\hline Lemna minor & 21 & $0.23 \pm 0.01$ & $\begin{array}{c}509.28 \pm 34.21 \\
95.50\end{array}$ & $\begin{array}{c}51.13 \pm 7.56 \\
96.00\end{array}$ & $0.0076 \pm 0.0011$ & $0.0051 \pm 0.0009$ \\
\hline
\end{tabular}

VMR - average daily ration volume; DPF - food transition (in digestive system) time; CAF - food assimilation coefficient; RDPE - daily excrement production rate; RDA - daily assimilation rate 


\section{DISCUSSION}

The two allospecies showed the same qualitative diversity of composition of their food masses (the food categories in their food ration) (Table 1) and the same degree of filling of their stomachs (Table 2). Soft water plants (flowering plants) and filamentous algae formed the majority of their food. However, the proportion of various food categories differed between the "western" and "eastern" allospecies (1:1 and 1:1.7, respectively). The probable reason was the predominance of filamentous algae at the Vorskla locality, where most of the samples were collected. The abundance of these snails in places with the slow water flow may be caused by their preference for stagnant waters, which was repeatedly observed for many great ramshorn populations in Eastern Europe (ZHADIN 1933, 1952, SUSHKINA 1949) and later for Ukrainian populations (LIUBYCHENKO et al. 2018, GARBAR et al. 2020). The proportion of flowering plants in the food rations of both allospecies was minor. Selection of food items by gastropods (ZERNOV 1949, JACKIEWICZ 1959, STADNYCHENKO 1994, ROMANENKO 2001, KRUGLOV 2005) is determined by, first, mechanical properties of the food and, second, by the energy conversion efficiency of the radula which shreds the food. Overall, the major part of their food volume is composed of plant tissue scraped by the radula. In our study, the proportion of tough plant material was 2.5 times higher for the "western" allospecies than for the "eastern" form. The greater ability of the former allospecies to consume this quite unattractive food is probably a result of the greater absolute body size in the "western" allospecies (GARBAR 2003, GARBAR \& GARBAR 2005, 2006, MEZHZHERIN et al. 2005); this is confirmed by our results. We assume that the greater body size is accompanied by the proportional growth of radula: odontophore, teeth and cusps. In both allospecies lateral teeth are the biggest and the sharpest, and thus the most functionally powerful; they are situated on both sides of the central tooth in each transverse row. Consequently, the scraped food particles which form the food mass, should be bigger in the "western" allospecies. The successful consumption of tough plant tissue by this form may possibly have been favoured by partial mowing (and thus mechanical destruction), which affected the coastal vegetation of tough hydrophytes in the Teteriv River at the time of sampling. Such damaged plant fragments are usually among the most accessible sources of this food category (SUSHKINA 1949, FRÖMMING 1956, SADCHIKOV \& KUDRYASHOV 2004).

Consumption of undamaged tough plants (Phragmites, Typha, Carex, Glyceria) is prevented by their well-developed mechanical tissue. The feeding snails consume the periphyton from their surface mainly bacteria and algae (green unicellular and diatomes), and small particles of plant debris.

The great ramshorns are obligate phytophages which feed on every plant available for successful foraging, mainly various soft plants, which they scrape with their radula. However, this point of view is not shared by all scientists. Particularly YA. STAROBOGATOV (personal communication), considering his data on the qualitative and quantitative food composition, insisted on exclusively bacteria-based feeding of $P$. corneus, while plants constituted random and rare food because of the weakness of the radula.

Comparison of the great ramshorn radula to the radulae of gastropods of comparable size (like Lymnaeidae) shows its apparent weakness (KRUGLOV 2005). However, its functional properties are sufficient for statistically probable ( $\mathrm{CV}=95.6-97.8 \%)$ feeding mainly on soft plants; this was repeatedly observed in laboratory and in the wild (e.g. SUSHKINA 1949, FRÖMMING 1956, TSIKHON-LUKANINA 1987, STADNYCHENKO 1994, LIUBYCHENKO et al. 2018).

The results of our research in the wild show that the "western" allospecies is 1.4-times more efficient as a consumer of plant detritus than the "eastern" allospecies. This may be accounted for by two facts: stronger (longer, sharper, more powerful) lateral teeth which hook and grab detritus particles more effectively; and thicker detritus layer in the Teteriv River (near Korchak) due to mowing of semi-aquatic plants along the river. Also, snails of both allospecies readily consumed animal tissue and detritus (including dead individuals of their own species) under aquarium conditions - only shells usually remained after a few days. Similar behaviour was reported by SUSHKINA (1949).

Other food categories (for the list and \% of consumption see Table 1) are random or unavoidable food items. Quantitatively predominating categories include bacteria, green unicellular algae and diatomes, consumed as part of periphyton and detritus. Such food items were 1.5-times more significant in the food ration of the "eastern" allospecies; we think that the reason is the higher qualitative diversity and greater richness of aquatic vegetation in the Vorskla River compared to the Teteriv River.

Allochthonous material was occasionally found in the food masses of both allospecies: tree and shrub leaves, pollen grains and seeds of flowering plants.

Bottom sediments (sand and mud), common to the two rivers, constituted an inseparable part of the food masses of both allospecies. They predominated in those categories of individuals which spend a significant portion of their life in benthal areas devoid of 
macrophytes. The main feeding mode of such snails is detritophagy, which involves unavoidable intake of bottom sediment particles. Such particles move with the food to the stomach and then to the intestine, and on the way they aid fragmentation of food particles (ZHADIN 1933, 1952).

In the laboratory experiments we ascertained the main six trophological indices for each allospecies when feeding on soft plants and on C. glomerata only (Table 3 ). Considering the small accessibility of tough macrophytes as food items due to the well-developed mechanical tissue, the food for experimental animals had to be provided shredded in $5-10 \mathrm{~cm}$ pieces. This would bias the results, since the animals would consume not only the softest parts of the tough food provided, but also its surface periphyton.

There were no statistically significant differences between the volumes of the allospecies' daily ration. Both of them consumed C. glomerata fairly readily. Concerning the soft macrophytes, the snails appeared to be quite similar in their daily ration preferences. It is obvious from the sequences food plants arranged in the order of preference: "western" allospecies - N. candida $>$ M. spicatum $>$ P. perfoliatus $>$ E. canadensis $>$ L. minor; "eastern" allospecies - N. candida $>$ M. spicatum $>P$. perfoliatus $>$ L. minor $>$ E. canadensis.

The rate of food passage through the digestive system is the important index of adaptation of these animals to their environment. The "western" allospecies showed the fastest increase in its value when fed with $P$. perfoliatus, and the "eastern" allospecies - with the diet of C. glomerata and L. minor.

The "eastern" allospecies had a significantly higher tissue (soft marophytes $N$. candida, P. perfoliatus, $L$. minor) assimilation coefficient than the "western" allospecies. This may be caused by the smaller total

\section{REFERENCES}

DANILOVA M. M. 1991. Pitaniye molodi ateriny Atherina boyeri Chernogo moray. Voprosy Ikhtiologiyi 31: 123129.

DUKA L. A., SINYUKOVA V. I. 1976. Rukovodstvo po izucheniyu pitaniya lichinok i malkov morskikh ryb $\mathrm{v}$ estestvennykh i ekperimentalnykh usloviyakh. Naukova Dumka, Kiev.

FRÖMMING E. 1956. Biologie der mitteleuropaischen Süswasserschnecken. Dunker und Humbolt, Berlin.

GARBAR D. 2003. Dyagnostichne znachenniya konkhologichnykh oznak mollyuskiv rodu Planorbarius (Bulinidae, Gastropoda, Pulmonata). Zhytomyr Ivan Franko State University Journal 11: 238-240. http://eprints.zu.edu.ua/id/eprint/3526

GARBAR D., GARBAR A. 2005. Kariologicheskiye osobennosti mollyuskov roda Planorbarius (Bulinidae, Gastropoda, body size and proportionally smaller radula, and especially by the smaller, thinner and thus sharper cutting edge of its lateral teeth. Therefore, the "eastern" allospecies obtains more shredded and thus more easily digested and assimilated food. This must result in obligate increase in energetic potential of this allospecies' populations (e.g. SUSHCHENYA 1975). This is supported by its higher values of the daily assimilation rate (RDA). The more rapid increase of the daily assimilation rate for the "eastern" allospecies may speak in favour of its more reliable adaptation to the more severe conditions of Left Bank Ukraine compared to the milder conditions of Right Bank Ukraine.

The ranges of the two allospecies (MEZHZHERIN et al. 2010, GARBAR et al. 2020), charted on the basis of ecological-climatic factors, correspond with their vicariant nature and with the empirical observations. Consequently, the above-cited authors assumed that the hybrid zone of the two forms was mainly stabilised by the ecological factors, since the distribution range of each allospecies coincided geographically with the regions with different probability of summer drought (MEZHZHERIN et al. 2006, GARBAR \& GARBAR 2006). Increasing aridisation poses a serious danger to these obligate phytophages.

Using climate modelling of the modern ranges for the "western" and "eastern" allospecies and their future possible changes (predicted till the 2050s), it was shown (GARBAR et al. 2020) that climate shifts might bring about a shrinkage of the ranges of both, but mainly of the "western" form. Considering this, we should expect decline in both the number and the density of their populations; this would be associated with impoverishment of species richness and biomass of aquatic vegetation (as their food basis) in their habitats.

Pulmonata) fauny Ukrainy. Mezhdunarodnaya Konferentsiya "Molod i postup biolohii". Spolom, Lviv: 254.

GARBAR A., GARBAR D. 2006. Genogeograficheskiy podkhod k sistematike mollyuskov na primere allopidovogo kompleksa Planorbarius corneus. Ecological-physiological and faunal aspects of malacological research, the role of molluscs in bioindication of the state of the environment 2: 57-59.

GARBAR A., BABYCH Y., STADNYCHENKO A., GARBAR D. 2020. Bioklimatichni osoblivosti ekologichnykh nish ta modelyuvannya dinamiki arealiv Planorbarius corneus $\mathrm{v}$ umovakh zmin klimatu. XI Vseukrainskaya NaukovoPraktichna Konferentsiya „Biologichni dostizhennya 2020”, 21-23 Bereznya 2020, Zbirnik Naukovih Prats. Zhytomyr: 150-153.

http://eprints.zu.edu.ua/id/eprint/31102 
JACKIEWICZ M. 1959. Badania nad zmiennością i stanowiskiem systematycznym Galba palustris O. F. Müll. Prace Komisji Biologicznej PTPN 19: 1-86.

KhLEBOVICH V. V. 1985. Akklimatizatsiya zhivotnykh. Nauka, Leningrad.

KRUGLOV N. 2005. Mollyuski semeystva prudovikov (Lymnaeidae Gastropoda Pulmonata) Evropy i severnoy Azii. Izdatelstvo SGPU, Smolensk.

LIUBYCHENKO I., STADNYCHENKO A., HYRYN V. 2018. Zalezhnist' velichini serednodobovogo ratsyony vitushki rogovoyi (Mollusca, Gastropoda, Pulmonata, Bulinidae) vid trivalosti umov desikatsiyi. XI Vseukrainskaya Naukovo-Praktichna Konferentsiya „Biologichni dostizhennya - 2018”, 14-16 Bereznya 2018, Zbirnik Naukovikh Prats. Zhytomyr: 183-184. http://eprints.zu.edu.ua/id/eprint/27110

MEZHZHERIN S., GARBAR D., GARBAR A. 2005 Sistematicheskaya stryktura kompleksa Planorbarius corneus s.l. (Gastropoda, Pulmonata): analiz allozimnykh markerov i morfologichesnykh priznakov. Vestnik Zoologii 39: 11-17.

http://eprints.zu.edu.ua/id/eprint/8961

MEZHZHERINS., GARBARD., GARBARA.2006. Resistematika mollyuskov roda Planorbarius (Gastropoda, Pulmonata) fauny Ukrainy: opyt resheniya problemy na osnovye genogeograficheskogo podkhoda. Reports of the National Academy of Sciences of Ukraine 9: 170-175. http://eprints.zu.edu.ua/id/eprint/9731

MEZHZHERIN S., TITAR V., GARbaR A., GARbaR D. KORSHUNOVA Ye., ZHALAY Ye. 2010. Mekhanizmy stabilizatsii gibridnykh zon u presnovodnykh mollyuskov (Gastropoda, Pulmonata): testirovanye gipotez putem modelirovaniya ekologicheskih nishi. Reports of the National Academy of Sciences of Ukraine 12: 144-149. http://eprints.zu.edu.ua/id/eprint/9729

Petrusewicz K., MaCFAdyen A. 1970. Productivity of terrestrial animals. Principles and methods. IBP Handbook 13, Blackwell Scientific Publications, Oxford und Edinburgh.
PEACOCK F., BUNTING S., QUEEN K. 1965. Serum protein electrophoresis in acrylamide gel patterns from normal human subjects. Science 147: 1451-1455. https://doi.org/10.1126/science.147.3664.1451

ROMANENKO V. 2001. Osnovy vodnoy ekologii. Oberehy, Kyiv.

SADCHIKOV A., KUDRYASHOV M. 2004. Ekologiya pribrezhnoy vodnoy rastitelnosti: Uchebnoye posobye. NIAPriroda, REFIA, Moscow.

SitNikOVA T. A., STARobogatov Y. 1985. Novyy prostoy sposob prigotovleniya preparatov raduly mollyuska. In: Starobogatov Y. (ed.). Novyye dannyye po sistematike i ekologii mollyuskov. Izdatelstvo ZIN SSSR, Leningrad, pp. 20-21.

STADNYCHENKO A. 1994. Lymnaeiformes: Physidae, Bulinidae, Planorbidae. Fauna Ukrainy. Naukova dumka, Kyiv.

SUSHCHENYA L. 1975. Kolichestvennyye zakonomernosti pitaniya rakoobraznykh. Nauka i Tekhnika, Minsk.

SUSHKINA A. 1949. Pitaniye i rost nekotorykh bryukhonogikh mollyuskov. Proceedings of the All-Union Hydrobiological Society Meeting 1949, Moscow: 118131.

TSIKHON-LUKANINA E. 1987. Trofologiya vodnykh mollyuskov. Nauka, Moscow.

VYSKUSHYENKO D. 2002. Response of the lake pond snail (Lymnaea stagnalis L.) to the effects of copper sulfate and zinc chloride. Hydrobiological Journal 38: 86-91.

ZERNOV S. 1949. Obshchaya gidrobiologiya. 2nd edition. Izdatelstvo Akademii Nauk SSSR, Moskva \& Leningrad.

ZHADIN V. 1933. Presnovodnye mollyuski SSSR. Lensnabtekhizdat, Leningrad.

ZHADIN V. 1952. Mollyuski presnykh i solonovatykh vod SSSR. Nauka, Moskva \& Leningrad.

Received: April 4th, 2021

Revised: June 9th/July 19th, 2021

Accepted: September 30th, 2021

Published on-line: October 27th, 2021 